Scripta Neophilologica Posnaniensia. Tom XIII, strony: 185-201

Wydział Neofilologii, Uniwersytet im. Adama Mickiewicza w Poznaniu, 2013 DOI 10.7169/snp.2013.13.15

\title{
MOTYW PIGMALIONA I KONCEPCJA NAOMIZMU NA PRZYKŁADZIE POWIEŚCI MILOŚĆ SZALEŃCA TANIZAKIEGO JUN'ICHIRŌ ORAZ JEJ ADAPTACJI FILMOWEJ
}

\author{
NIKODEM KAROLAK, ESTERA ŻEROMSKA
}

Punktem wyjścia do napisania tego artykułu była lektura tekstu Alicji Helman (ur. 1935) Portrety filmowe - Pigmalion w miesięczniku „Kino” (nr 10/2010). Autorka, oprócz naturalnie przywołania greckiego mitu, zestawiła całkowicie różniące się od siebie sylwetki męskich protagonistów, dążących do odkrycia bądź stworzenia wymarzonego przez siebie kobiecego ideału. Byli to między innymi: specjalista od angielskiej wymowy Higgins z dramatu Bernarda Shawa, niespełniony pisarz Luis z filmu Carlosa Saury Elizo, moje życie (Elisa, vida mia , 1976) czy Hideo - przeciętny mieszkaniec Tokio z filmu Koreedy Hirokazu Dmuchana lala (Kūki ningyō, 2009). Hołubione przez nich kobiety to kolejno: pochodząca z nizin społecznych kwiaciarka, porzucona córka, nadmuchiwana lalka. Świadczą one o tym, że ideał i gust są pojęciami względnymi. Treść japońskiego filmu kojarzy się z powieścią wybitnego japońskiego pisarza Tanizakiego Jun'ichirō (1886-1965) Chijin no ai (Miłość szaleńca, 1925), a zwłaszcza z jej głównym bohaterem. „Przygarnia” on do siebie Naomi - pracującą w jednej z tokijskich kawiarni piętnastoletnią dziewczynkę - i zaczyna ją wychowywać tak, by w przyszłości stała się idealną kobietą, którą mógłby potem poślubić. Odwołanie, a ściślej trawestacja greckiego mitu, wydaje się jawna. Naomi jest bowiem w powieści Tanizakiego posągiem Galatei, urasta do rangi boskiej istoty. Po przebudzeniu się do życia (u Tanizakiego: po wejściu w dorosłość) odrzuci jednak swojego twórcę - zaślepionego jej pięknem Pigmaliona. 
Istotną rolę w życiu japońskiego pisarza odegrały kobiety. Jako dziecko silnie związany był on z matką, która traktowała go jak skarb i zawsze starała się być przy nim. To jej Tanizaki poświęcił później jedno ze swoich najsłynniejszych opowiadań Ulotny most snów (Yume no ukihashi, 1950). Podobnie młodzieńcza miłość do Fukuko oraz uczucie, którym darzył swoją ostatnią żonę Matsuko zaowocowały portretami psychologicznymi kobiet w takich utworach, jak Atsumono (Goracy rosót, 1912) czy Ashikari, czyli źle mi bez ciebie (Ashikari, 1932). Powieści i opowiadania Tanizakiego thumaczono na wiele języków obcych. $\mathrm{Na}$ ich temat powstały też liczne książki i eseje traktujące przede wszystkim o sposobie przedstawiania kobiet w jego utworach oraz powikłanych relacjach między kobietami i mężczyznami. Twórczość Tanizakiego stale budzi wiele kontrowersji i dzieli czytelników na tych, których zachwyca estetyczny i wysublimowany sposób opisu kobiecej urody, oraz na tych, którzy postrzegają jego utwory jako zapis aberracji seksualnych i widzą w nich jedynie potrzeby niespełnionego fetyszysty kobiecych stóp. W artykule podjęto jednak próbę udowodnienia, że miłość w powieściach Tanizakiego ma w sobie pierwiastek sacrum. Nawet jeśli miejscami wydaje się nam ona nadmiernie lubieżna lub dziwaczna, to jeśli kochankom to nie przeszkadza, nie możemy im jej zabronić.

Odwołanie do mitu Pigmaliona w powieści Tanizakiego Miłość szaleńca zostało już wcześniej zasugerowane w książce Stefana Janickiego Film japoński. Nieliczne wzmianki na ten temat znaleźć też można w eseju Yiju Huang'a „A Man Awakened from Dreams: Rereading the Modern Girl Image in A Fool's Love by Tanizaki Jun'ichirō". Tanizaki, doskonale obeznany w literaturze światowej, kiedy kreował postać buntowniczej Naomi, miał z pewnością na uwadze portret Elizy z dramatu Shawa Pigmalion. Nawiązanie do mitu z zawarciem licznych groteskowych elementów świadczy natomiast niewątpliwie o trawestacyjno-satyrycznym charakterze utworu. W moim artykule chciałem rozwinąć to, jak na razie jeszcze szeroko nieopisane zagadnienie, ilustrując sposób, w jaki starożytny mit grecki ewoluował na przestrzeni wieków na różnych kontynentach.

\section{Od greckiego mitu do dramatu Bernarda Shawa Pigmalion}

Ze źródeł greckich niewiele wiadomo o cypryjskim królu Pigmalionie. Ta mityczna postać wywarła jednak olbrzymi wpływ na szereg dzieł literackich, filmowych, utworów muzycznych czy teatralnych. Ucieleśnia ona bowiem ludzkie pragnienie poszukiwania ideału, pragnienie stworzenia czystej, doskonałej formy. Mityczny Pigmalion oprócz władania swoim królestwem trudnił się sztuką rzeźbiarską. Pewnego dnia wykonał posąg odzwierciedlający jego pragnienia - 
posąg kobiety „tak cudnej, jakiej nie było wówczas na ziemi”"1. Po jego ukończeniu zakochał się w swoim dziele, popadając tym samym w rozpacz, gdyż nieżywa materia nie mogła odwzajemnić jego uczuć. Całe to zajście obserwowała bogini Afrodyta, która w Pafos na Cyprze miała swoją świątynię, gdzie lubiła spędzać czas. Nie mogąc znieść przykrego widoku Pigmaliona karmiącego i pojącego swój posąg, Afrodyta tchnęła weń życie. Zatopiony w miłości i cierpieniu ujrzał, jak posąg budzi się do życia, dotykając jego ramienia. Ożywioną kobietę nazwał Galateą, po czym uczynił ją swoją żoną. Urodziła mu ona syna Pafosa, który w przyszłości założy miasto, a w nim zbuduje świątynię w podzięce bogini. Według innego źródła ${ }^{2}$ Pigmalion jest nieszczęśliwie zakochany w Afrodycie, która nie odwzajemniła jego uczuć. Zrezygnowany i zrozpaczony zbudował on posąg na jej podobieństwo, a bogini ulitowawszy się ożywiła go. W ten sposób narodziła się Galatea - kobieta, której pierwowzorem była grecka bogini miłości. Druga wersja mitu, zawierająca to istotne dopełnienie, wydaje się również bardzo przekonująca. Afrodyta, mająca wyłonić się z morskiej piany niedaleko Cypru, zawsze otoczona była bowiem gronem adoratorów. Cudowna przepaska, którą nosiła, wyzwalała pożądanie i uległość nie tylko ludzkich, ale i boskich serc. Pigmalion nie musiał zatem być wcale sam sobie winien, że uległ jej urokowi. $Z$ greckim mitem łączy się pojęcie pigmalionizm oznaczające specyficzny sposób patrzenia mężczyzny na kobietę, poszukiwanie w niej własnej tożsamości, a także uzależnianie jej od siebie. Mit wskazuje na odwieczny problem poszukiwania ideału miłości, na to, jak bardzo skomplikowane są stosunki międzyludzkie, a wreszcie na to, jak bardzo uczucia narcystyczne i egocentryczne rządzą naszymi emocjami. Motyw ten ma w pewnym sensie swój zalążek już w opowieści biblijnej o Adamie i Ewie, w której kobieta zostaje zrodzona z żebra Adama. Powstaje ona nie jako integralny byt, ale także jako sui generis, kopia integralnej jednostki ludzkiej. ${ }^{3}$ Można w związku z tym uznać, że w gruncie rzeczy każdy z nas jest w pewnym sensie taką kopią, bo jest dzieckiem swoich rodziców i dziedziczy cechy po swoich przodkach. Mityczny Pigmalion wchodzi w rolę ojca, bo Galatea jest jego dziełem. Przez wieki, od czasów najdawniejszych do współczesnych, z mitu tego wyłania się portret kobiety jako pewnego wytworu męskiej fantazji. Jawi się ona nie jako osoba, lecz jako sztuczny twór wyobraźni, którego kreacja przynosi spełnienie. Mitologiczny król poślubił swą Galateę i żył długo i szczęśliwie.

Dla współczesnych Pigmalionów los nie był już jednak tak łaskawy, jak na przykład dla jednego z najsłynniejszych z nich, czyli głównego bohatera sztuki George'a Bernarda Shawa (1856-1950), zatytułowanej Pigmalion (1912). Na

\footnotetext{
${ }^{1}$ Parandowski, J. 1992. Mitologia. Londyn: Puls. 87.

${ }^{2}$ Graves, R. 1968. Mity greckie. Warszawa: Państwowy Instytut Wydawniczy. 199.

${ }^{3}$ Helman, A. 2010. „Portrety filmowe: Pigmalion”. Kino 10. 67.
} 
uwagę zasługuje fakt, że autor żył w czasach panowania królowej Wiktorii (1937-1901), uchodzących za okres zakłamania i pruderii. Utwory Shawa, odznaczające się stylem realistycznym bądź naturalistycznym, są wyrazem jego poglądów życiowych i koncepcji filozoficznych, demaskującymi kpiną ówczesną obłudę i snobizm klasy nowobogackiej czy arystokracji. Edmund Misiołek we wstępie do Pigmaliona pisze, że Shaw w swoich utworach nie tylko przyjmował postawę krytyczną wobec reform społecznych, ale też szukał rady i lekarstwa na odkłamanie obyczajowości:

„Shaw wierzył w możliwość etycznego rozwoju człowieka - i jego sztuki do dziś dają wyraz tej wierze, wciąż od nowa przywracając szacunek rzeczom naprawdę godnym szacunku i zdzierając płaszcz cnoty z tego, co się weń dla własnych korzyści przybrało". ${ }^{4}$

Mimo akcentów humorystycznych trudno uznać Pigmaliona Shawa za gatunek komediowy. Jest to raczej sztuka o człowieku, który nie potrafi wyzwolić się ze swojego egocentryzmu i nie może przełamać się wewnętrznie w stosunku do kobiet. Autor określał swój utwór jako przygodę romantyczną i starał się za wszelką cenę uniknąć szczęśliwego zakończenia. ${ }^{5} \mathrm{~W}$ tym dramacie pojawiają się sceny komediowe o zabarwieniu ironicznym, mające na celu zdemaskowanie dyskretnego, fałszywego uroku angielskiej burżuazji i ,śmietanki” towarzyskiej. Shaw zaczerpnął elementy humorystyczne $\mathrm{z}$ dzieł swoich poprzedników, w tym także z burleskowego utworu Williama Schwenka Gilberta zatytułowanego Pygmalion and Galatea, an Original Mythological Comedy ${ }^{6}$ (1871), w którym posąg Galatei budzi się do życia, mieszając szyki małżeńskiej parze. Nazywany przez niektórych „Wielkim Kpiarzem” irlandzki dramaturg i prozaik wykreował w Pigmalionie postać profesora fonetyki, Henryka Higginsa, który postanawia założyć się z przyjacielem, pułkownikiem Pickeringiem, o to, że w ciągu pół roku nauczy prostą kwiaciarkę z londyńskich slumsów języka, jakim się posługują arystokratki, a następnie wprowadzi ją na salony księżnej. Higgins, jako spiritus movens całego przedsięwzięcia, „rzeźbi” swoje dzieło, szlifuje je, pieczołowicie dbając o każdy detal. Wykuwanie posągu z nieobrobionej materii łączy go z mitologicznym Pigmalionem. Ta wynikła z zakładu więź artysty i stworzonego przez niego dzieła uchodziła wśród krytyków za jedno z oryginalniejszych rozwiązań w dziejach dramatu. Higgins po udowodnieniu wyższości tez Miltona, pozostawia jednak wykreowaną przez siebie Elizę-Galateę samej sobie, bo już jej nie potrzebuje. Pozostaje niewzruszony w swoim egoizmie. Cierpi na atrofię uczuć, potrafi zmienić drugiego człowieka, ale nie umie zmienić sam siebie. Jest jednak kilka oznak świadczących o tym, że mimo wszystko

\footnotetext{
${ }^{4}$ Shaw, B.G. 1977. Pigmalion. Warszawa: Państwowy Instytut Wydawniczy. 7.

${ }^{5}$ Tamże, s. 8.

${ }^{6}$ Nie ukazało się tłumaczenie w języku polskim.
} 
czuje pustkę po odejściu Elizy. Szukał jej bowiem jak zagubionej parasolki i nagle spostrzega, że kobieta ta odegrała istotną rolę w jego życiu. Podobnie porzucona Eliza czuje się nieswojo, bo nie może znaleźć dla siebie miejsca w nowym środowisku. Nie poślubiłaby jednak swojego mentora nawet wówczas. gdyby ten ją o to błagał. Autor sztuki skomentował tę sytuację w posłowiu: „Galatea nigdy nie kocha Pigmaliona bez zastrzeżeń. Jego stosunek do niej jest zbyt bogopodobny, aby mógł być całkowicie przyjemny"7.

W dramacie Shawa istotną kwestią jest nawiązanie do filozofii Henriego Bergsona (1859-1941) i jego koncepcji élan vital (pędu życiowego), której był gorącym zwolennikiem. Nawiązując głównie do tej właśnie koncepcji, autor sztuki oparł zamysł przywołania greckiego mitu. Siła woli i życiowy pęd są niezbędne do osiągnięcia stanu harmonii, stworzenia dzieła o boskich atrybutach. Do tej myśli będą też niejednokrotnie nawiązywać współcześni japońscy pisarze zainspirowani europejską teorią literatury i filozofii.

Główni bohaterowie Pigmaliona odznaczają się cechami archetypicznymi. Wynika to zapewne z tego, że Shaw nawiązuje również do jungowskiej psychoanalizy i przyznaje, że jego proces twórczy wynika z „halucynacji”. Początkowo w wyobraźni autora wyłaniają się jedynie sylwetki bohaterów i pierwsze ich dialogi. Pisząc sztukę, Shaw nie kierował się żadnymi odgórnymi regułami czy zasadami moralnymi. ${ }^{8}$ Jego Higginsa i Elizę, determinuje środowisko, w którym się wychowali. Archetypy mentora-twórcy i ucznia podążającego za jego głosem ścierają się ze sobą, gdyż pochodzą z dwóch zupełnie różnych środowisk. Postanowienie Higginsa wydaje się z założenia niedorzeczne. Zakłada on bowiem ingerencję w to, co determinuje środowisko. Krytycy wyrażali się o Higginsie nie jako o dojrzałym mężczyźnie, ale jako o „przedwcześnie rozwiniętym, zawziętym chłopcu" ", który mimo aspiracji i szerokich horyzontów myślowych odznacza się niedojrzałym, chłopięcym charakterem. Higgins próbuje jednak wejść zarówno w rolę mentora, jak i w rolę ojca Elizy. Ona zaś nie daje się podporządkować. Oświadcza tryumfalnie: „Ah-ah-ah-au-oo! Myślałby kto, że pan jest moim ojcem" 10 .

Motyw wchodzenia w rolę ojca stanie się istotny dla bohatera japońskiej powieści Miłość szaleńca Tanizakiego Jun'ichirō. Tytułowy szaleniec (odpowiednik Pigmaliona) będzie się usilnie starać postępować podobnie jak Higgins, ale w rezultacie stanie się więźniem własnego dzieła.

\footnotetext{
${ }^{7}$ Tamże, s. 167.

${ }^{8}$ Reynolds, J. 1999. Pygmalion's wordplay: the postmodern Shaw. Gainesville, FL: University of Florida Press. 78.

${ }^{9}$ Tamże, s. 83.

${ }^{10}$ Shaw, B.G. 1977. op. cit. 50.
} 


\section{Od pigmalionizmu do naomizmu - powieść Mitość szaleńca a adaptacja filmowa}

Tanizaki Jun'ichirō (1886-1965) w powieści Niektórzy wola pokrzywy (Tadekūmushi, 1929) ${ }^{11}$ włożył w usta narratora następujące słowa:

„(...) A kiedy stykał się z zachodnią powieścią, muzyką czy filmem, wydawało mu się, że w jakimś stopniu spełniają się jego tęsknoty, zwłaszcza że na Zachodzie od dawna otaczano kobietę szczególnym kultem. Europejczyk w kochanej przez siebie kobiecie widzi boginię z mitów greckich czy obraz Świętej Dziewicy. To odczucie jest szeroko rozpowszechnione, wpływa na obyczaje i znajduje odzwierciedlenie w sztuce i literaturze Zachodu. Kaname czuł ${ }^{12}$ niewysłowiony smutek, gdy myślał o życiu emocjonalnym Japończyków, w którym brak tego szczególnego kultu. Nie można co prawda powiedzieć, że w Japonii nie znane były wzniosłe uczucia, towarzyszyły one klasycznej powadze i surowości literatury starożytnej i teatru średniowiecznego $\overline{n o}^{13}$, wspierających się na buddyzmie, jednak wraz z nastaniem epoki Tokugawa ${ }^{14}$ i malejącym wpływem buddyzmu uczucia te stają się coraz słabsze. Kobiety przedstawiane przez Saikaku ${ }^{15}$ czy Chikamatsu $^{16}$, łagodne i czułe, tonące we łzach u stóp mężczyzny, nie są to na pewno istoty, przed którymi mężczyźni padać by musieli na kolana (...)."17

Ten fragment jest bardzo charakterystyczny dla twórczości Tanizakiego, w której przeciwstawia on japońską kulturę kulturze zachodniej, wplatając do fabuły swoich utworów wątki mniej lub bardziej wyemancypowanej miłości. Tanizaki nigdy nie krył swojej fascynacji Zachodem i europejskim stylem życia, którego nie miał możliwości poznać $\mathrm{z}$ autopsji, a jedynie $\mathrm{z}$ książek, filmów i dzięki obserwacji stopniowych zmian cywilizacyjno-kulturowych zachodzących w kraju. Bacznie się im przyglądał, ale zdawał sobie sprawę z tego, że mi-

${ }^{11}$ Tytuł ten jest odpowiednikiem polskiego powiedzenia: „O gustach się nie dyskutuje”.

${ }^{12}$ Główny bohater w głębi serca jest rozdarty między upodobaniem do japońskiej tradycji a fascynacją tym, co zachodnie i nowoczesne.

${ }^{13} \mathrm{No}$ - jeden z trzech głównych gatunków teatru japońskiego obok kabuki i ningyo jōruri (od XIX w. bunraku), ukształtowany na przełomie XIV i XV wieku.

${ }^{14}$ Okres Edo (inaczej: Tokugawa; 1603-1868) - rządy shōgnów z dynastii Tokugawa, centralizacja władzy i etap feudalizmu w Japonii.

${ }^{15}$ Ihara Saikaku (1642-1693) - wybitny pisarz, autor licznych książek obyczajowych i erotycznych, której bohaterami są mieszczanie i samuraje. Po polsku ukazała się powieść Kōshoku ichidai onna (wydanie polskie: Żywot kobiety swawolnej, tłum. J. Kordzińska-Nawrocka, Wydawnictwo Trio, Warszawa 2011).

${ }^{16}$ Chikamatsu Monzaemon (1653-1725) - jeden z najwybitniejszych japońskich dramaturgów, nazywany japońskim Szekspirem.

${ }^{17}$ Tanizaki J. 1972. Niektórzy wola pokrzywy. Warszawa: Państwowy Instytut Wydawniczy. 185 . 
mo szybko postępującego procesu westernizacji, pełna przemiana japońskiego społeczeństwa, a w tym emancypacja kobiet, nie dokona się za jego życia. Marzenia autora o nowoczesnym społeczeństwie japońskim, kontrast między młodością i starością, wreszcie miłosna opozycja sfery sacrum i profanum to - można powiedzieć - trzy główne idee uwypuklone przez autora, którego czekała jednak długa droga do osiągnięcia literackiego sukcesu. W 1910 roku redaktorzy pisma „Shinshichō” („Nowe Prądy”) opublikowali jego pierwsze dramaty: Narodziny $($ Tanjō) i Stoń $(Z \bar{o})$. W miesiąc później ukazało się do dziś szokujące, krótkie opowiadanie Tatuaż (Shisei) uważane często za pierwszy właściwy debiut Tanizakiego. W nim po raz pierwszy można dostrzec motyw pigmalionizmu, który potem autor rozwinie w Miłości szaleńca.

W Miłości szaleńca Tanizaki narrator wyznaje:

„Postaram się zrelacjonować dzieje mojego, być może nie mającego żadnego wcześniej odpowiednika, związku małżeńskiego, najdokładniej jak tylko potrafię, krok po kroku tak jak to było. Zapis ten będzie nie tylko świadectwem tych cennych i trudnych do wyparcia z mej pamięci zdarzeń, które mnie spotkały, ale i mam nadzieję, że czytelnikowi posłuży on jako punkt odniesienia. Japonia coraz bardziej objawia swe kosmopolityczne oblicze, Japończycy nawiązują kontakty z obcokrajowcami, przekonują się do różnorodnych doktryn i ideologii. Zarówno mężczyźni, jak i kobiety starają się być coraz to bardziej nowocześni ${ }^{18}$ - takie oto nastały czasy. Dotychczas nie było związków podobnych do mojego, ale myślę, że zacznie ich stopniowo przybywać (...).",19

Uwagę zwraca pierwszoosobowa narracja typowa dla stylu pamiętnikarskiego, wyznaniowego. Tanizaki posłużył się literackim zabiegiem mimetyzmu formalnego, wplatając do powieści fragmenty osobistego dziennika, które wzmacniają wrażenie wypowiedzi i nadają jej typowo odautorski charakter. Zabieg ten, podobnie jak wszechobecne monologi wewnętrzne, składa się na głęboki psychologizm każdego bohatera powieści Tanizakiego.

Miłość szaleńca zaczęto publikować w odcinkach w gazecie „Asahi Shinbun” („Gazeta Asahi”) w marcu 1924 roku. Mimo że czytelnicy przyjęli książkę bardzo entuzjastycznie, cenzura nie była łaskawa i po szesnastym rozdziale kazano autorowi zaprzestać dalszych publikacji. Tanizaki obiecał jednak czytelnikom, że powieść dokończy i wkrótce wszystkie następne odcinki ukazały się na łamach magazynu „Josei” (Kobieta). Dlaczego krytyka zareagowała tak stanowczo, uznając utwór za gorszący?

Miłość szaleńca traktuje o relacji mężczyzny w średnim wieku o imieniu Jōji i młodziutkiej dziewczynie Naomi, którą ten bierze pod swe opiekuńcze skrzy-

\footnotetext{
${ }^{18} \mathrm{~W}$ powieści zostało celowo użyte słowo haikara - oznaczające coś jaskrawego, modnego, najczęściej w zachodnim stylu.

${ }^{19}$ Tanizaki J. 1925. Chijin no ai. Tokio: Schinchōsha. 5. (tłum. N. Karolak).
} 
dła. Kiedy się poznają, on ma lat dwadzieścia osiem i jest dobrze sytuowanym, szanowanym inżynierem, a ona - raptem piętnastoletnią, pochodzącą ze slumsów dziewczynką, pracującą w jednej z licznych kawiarnii w Asakusa. ${ }^{20}$ Głównego bohatera absorbuje nie tylko niewinność i ponętność Naomi, ale też jej imię. Tanizaki opisuje to w następujący sposób:

„W pracy wszyscy wołali na nią Nao-chan ${ }^{21}$, ale w rzeczywistości nazywała się Naomi. To imię niezwykle pobudzało moją ciekawość. Zacząłem myśleć, jakież jest ono wspaniałe, a zapisane alfabetem łacińskim nie różniło się wcale od imion obcokrajowców! Sprawiło to, że stopniowo zacząłem się nią coraz bardziej interesować. Naomi miała nietypowe imię, zachodnie rysy i do tego zdawała się być całkiem pojętna.

Szkoda by było zostawić ją tutaj, żeby marnowała się w tej kawiarni - pomyślałem. (...) Była trochę podobna do gwiazdy filmowej Mary Pickford i faktycznie coś miała w swoim wyglądzie z cudzoziemki. Proszę mi wierzyć, nie żebym patrzył przychylnym okiem na jej urodę, teraz kiedy mieszkamy już razem jako mąż i żona wiele osób ma o niej takie samo zdanie (...)."22

Jōji bierze początkowo cichą, spokojną i posępną Naomi do siebie, zapewnia jej komfortowe mieszkanie, opiekę, edukację i wszelkie wygody. Już w pierwszym rozdziale pojawia się motyw kinematografii, którą zafascynowany jest główny bohater Miłości szaleńca. Film wypełnia jego samotne życie, z czasem jednak zacznie on chodzić do kina wraz z Naomi do kina. Chce w niej widzieć jakby gwiazdę zachodniego kina, na przykład drugą Mary Pickford (18921979). Sugeruje więc swojej ukochanej, by się do niej upodobniała. Jōji wejdzie najpierw w rolę jej przyjaciela, potem ojca (którego jedyny kontakt fizyczny z Naomi polega na regularnym kąpaniu jej jak małej dziewczynki), wreszcie w rolę stopniowo coraz bardziej poddanego i uległego męża. Ostatecznie zostaje zdradzaną, oszukiwaną i wykorzystywaną marionetką - tytułowym szaleńcem. Naomi z małej, ,przezroczystej jak szklanka” dziewczynki przemieni się w groźnego wampa. Nic więc dziwnego, że krytyka była oburzona propagowaniem takiego ideału kobiety oraz różnych anomalii seksualnych bohaterów powieści.

O adaptacji filmowej Miłości szaleńca pisze Stanisław Janicki w książce Film japoński:

„(...) Zakochany idiota ${ }^{23}$ to opowieść o miłości mężczyzny w średnim wieku i młodej dziewczyny. On jest człowiekiem cenionym, dobrze sytuowanym i statecznym: nie pije, nie pali. Ona przeciwnie - rozbrykana, o temperamencie nie do okiełznania, nie znająca umiaru i nie mająca skrupułów. On - niczym Pigmalion - chce ze swej Galatei uczynić

\footnotetext{
${ }^{20}$ Asakusa - dzielnica Tokio, w XX wieku jedna z popularniejszych dzielnic rozrywkowych.

${ }^{21}$-chan - sufiks w języku japońskim sugerujący pieszczotliwe zdrobnienie.

${ }^{22}$ Tanizaki J. 1925. op.cit. 6. (thum. N. Karolak).

${ }^{23} \mathrm{~W}$ książce S. Janickiego pozycja widnieje pod tym tytułem.
} 
kobietę własnych marzeń. Ale ona wodzi go za nos, okłamuje, zdradza. Wraca jednak, bo przecież oboje nie mogą bez siebie żyć (...).,24

W istocie jest dokładnie tak, jak pisze Janicki. Jōji, starając się świecić przykładem, wychowując ją i opłacając jej lekcje języka angielskiego i zajęcia muzyczne, staje się jakby Pigmalionem rzeźbiącym swój posąg idealnej kobiety, czyli w tym wypadku nowomodnej, o cechach i przymiotach zachodniej dziewczyny („,western girl”). Naomi ma nie tylko nietypowe imię. Różni się zachowaniem i wyglądem od typowej Japonki, spełnia wszystkie wymogi jako „materia” na posąg. Szybko jednak okazuje się, że zmuszana do nauki jest oporna i buntownicza, podobnie jak początkowo Eliza z dramatu Shawa.

W japońskiej trawestacji mitu o Pigmalionie i Galatei następuje nieoczekiwany zwrot akcji. Posąg, budząc się własnego twórcę zdominuje i zamieni go w swojego niewolnika, karze mu sobie dogadzać i spełniać wszystkie pragnienia. Pigmalion nie będzie miał wyboru. Całkowicie zapatrzony w piękne kształty swojego posągu, odda wszystko, by mieć go choć czasem przy sobie. Mimo to można wyróżnić wspólne cechy Naomi i Elizy. Są to ich niskie pochodzenie społeczne oraz - zdeterminowany środowiskiem, w którym się wychowali kolokwialny sposób wysławiania się. Styl wypowiedzi bohaterek jest potoczny, ale różni się pod względem formalnym i składniowym. Naomi mówi jak mała, przymilająca się, prosząca błagalnie o nową zabawkę dziewczynka, która celowo posługuje się przesadnymi zmiękczeniami. Język Elizy natomiast, w okresie poprzedzającym jej przemianę, cechuje wulgarność.

Do kwestii poprawności wypowiedzi mężczyźni w obu utworach mają odmienny stosunek. Jōji z Miłości szaleńca Tanizakiego, w przeciwieństwie do Higginsa z Pigmaliona Shawa nie jest naukowcem, brakuje mu odpowiednich kompetencji i nie stara się też zmienić sposobu mówienia Naomi. Postanowił jedynie wychować ją na inteligentną, budzącą zachwyt „zachodnią dziewczynę” (western girl), którą mógłby zamknąć u siebie w domu i mieć do niej wyłączne prawo. W rezultacie jednak Jōji również kieruje się egoizmem, marząc o tym, aby uczynić z Naomi - jak sam mówi - substytut ćwierkającego ptaszka w klatce czy własnej pokojówki. Przygarniając Naomi do siebie, ma nadzieję, że będzie ona dla niego jednym i drugim. Jōji nie jest jednak tak jak Higgins mizoginem, ani tyranem - wręcz przeciwnie - jest wątły i słaby, ogłupiały z miłości.

Motyw kreowania idealnego wizerunku jest w Miłości szaleńca jawnym nawiązaniem do greckiego mitu. Naomi-Galatea po przemianie zyska pewność siebie i władczość, nie pokocha jednak swojego artysty, który stanie się dla niej kolejną zabawką, co chwilę porzucaną. Język Naomi ulegnie, co ciekawe, samoistnej przemianie - stopniowo, gdy bohaterka zacznie zdobywać przewagę nad

\footnotetext{
${ }^{24}$ Janicki, S. 1982. Film japoński. Warszawa: Wydawnictwa Artystyczne i Filmowe. 157.
} 
Jōjim, zmieniając ton na oschły, rozkazujący i władczy. Pod koniec powieści stanie się ona właściwie tworem androgenicznym, istotą o kobiecej aparycji, ale gwałtowną i porywczą, o męskim charakterze. Podobnie jak w przypadku bohaterki Tatuażu, na plecach Naomi pojawi się symboliczny pająk, ale stanie się on zwiastunem wyzwolenia się japońskiego społeczeństwa z kajdan wielowiekowej kultury konwenansów, zwiastunem nadejścia ery niezależnej i seksualnie wyzwolonej współczesnej dziewczyny (modan gāru ${ }^{25}$ ), a wraz z nią nurtu nazwanego naomizmem.

W latach dwudziestych i trzydziestych XX wieku w Japonii jedną z oznak westernizacji była rewolucja seksualna. W tym dekadenckim okresie burzono tradycję i konwenanse, zachowywano się swobodnie i swawolnie, ceniono głównie to, co stylowe i zachodnie. Tanizaki w swoich esejach zaznaczał, że do tych zmian przyczyniła się w dużej mierze literatura i film zachodni. Zwracał też uwagę na stopniową zmianę pozycji kobiet, które z przywiązanych do jednoznacznie określonego $\mathrm{w}$ stratyfikacyjnym społeczeństwie miejsca stawały się coraz bardziej wyzwolone, niezależne zawodowo i intelektualnie. Stopniowo zaczynały otwarcie głosić własne poglądy, angażować się w działalność walczących o prawa i równouprawnienie organizacji feministycznych, takich jak Stowarzyszenie Niebieskich Trzewików (Seitōsha ${ }^{26}$ ), Stowarzyszenie Nowych Kobiet (Shin Fujin Kyōkaii ${ }^{27}$ ), Stowarzyszenie Czerwonych Fal $\left(\right.$ Sekirankai $^{28}$ ). Hasło bunmei kaika (cywilizacja i oświecenie) ${ }^{29}$ przyświecało westernizacji i przyjmowaniu z Zachodu nie tylko zwyczajów, ale również wynalazków, strojów, muzyki czy biżuterii. Istotny również był, co zaznaczał niejednokrotnie Tanizaki, taniec towarzyski, jak walc czy fokstrot. Taniec wyzwalał młodzieńczą energię, której pozbawiona jest na przykład tradycyjna ceremonia herbaciana. Akcja jednego z rozdziałów Miłości szaleńca rozgrywa się w całości w sali tanecznej, do której Naomi udaje się z Jōjim na bankiet. Wcześniej przygotowywała się na kursie prowadzonym przez Rosjankę o wykwintnych manierach. Tanizaki ironicznie wyśmiewa zachowanie Naomi, która próbuje uczyć swojego Pigmaliona właściwej „etykiety”, każąc mu zwracać się do siebie używając słowa „Pani”. O zagrażających jej konkurentkach powiada, że są pozbawione gu-

${ }^{25}$ Modan gāru pochodzi od angielskiego modern girl.

${ }^{26}$ Organizacja założona przez słynną japońską feministkę Hiratsukę Raichō w 1911 r.

${ }^{27}$ Ugrupowanie założone przez Hiratsukę Raichō, Ichikawę Fusae i Oku Mumae w 1919 r. walczące o prawa ochrony kobiet.

${ }^{28}$ Ugrupowanie zabarwione ideologią socjalistyczną walczące o równouprawnienie kobiet, założone przez Yamakawę Kikue w $1921 \mathrm{r}$.

${ }^{29}$ Pod koniec XIX wieku w Japonii propagowano naśladowanie zachodnich wzorców, przebudowę gospodarki oraz rozwój nauki i technologii. Jednym z ówczesnych haseł nawołujących do szybkiego postępu było właśnie bunmei kaika. 
stu, kokietując nowo poznanych mężczyzn. Jōji, jakby trochę zagubiony, nie potrafiący odnaleźć się w takiej atmosferze, jawi się w rzeczywistości jako autor powieści, który choć pobierał lekcje tańca u Rosjanina, tańczył dość niezręcznie i zawsze miał wrażenie, że zawsze był jednym z gorszych na parkiecie. Główny bohater Mitości szaleńca staje się porte-parole autora. To w jego imieniu wypowiada się i komentuje otaczającą go rzeczywistość.

Na powieść i kreację bohaterów głęboki wpływ miała siostra żony Tanizakiego - Seiko. Poznał ją, gdy Seiko była jeszcze czternastoletnią dziewczynką i zaczął wychowywać, ponieważ dostrzegł w niej cechy „modernistycznej” kobiety. Seiko jednak, wbrew jego oczekiwaniom, została gejszą, a następnie aktorką prowadzącą swawolne życie. Tanizaki nie potrafił na długo utrzymać jej przy sobie. To właśnie Seiko stała się prototypem Naomi i kilku innych bohaterek stworzonych przez pisarza ${ }^{30}$. Pod terminem naomizm nie kryje się jedynie zwyczajna japońska femme fatale, ale - można powiedzieć - cały znacznie szerszy nurt w kulturze i literaturze eksponujący kobiety mające cechy bohaterki powieści Tanizakiego. Kobieta była nie tylko - zgodnie z najnowszą modą seksualnie wyzwolona i uwodzicielska, ale też lubiła włóczyć się po dzielnicach dużego miasta i jego modnych sklepach (ginbura) ${ }^{31}$. W swojej powieści Tanizaki przekroczył dodatkowo pewne bariery obyczajowo-moralne, podkreślając erotyczne fantazje bohaterów, a zwłaszcza przemianę Naomi z nieśmiałej dziewczyny w kapryśną i wyuzdaną nimfetkę. Naomizm i styl modan gāru znalazły swych kontynuatorów we wspomnianych ugrupowaniach feministycznych.

Wizerunek współczesnej kobiety w japońskiej literaturze i filmach nie był jednak jednowymiarowy. Niekiedy przedstawiano ją jako istotę bierną, za dnia spędzającą czas na plaży, a nocą włóczącą się po ulicach miasta. Czasem postrzegano ją jako zimną i wyrachowaną manipulantkę, innym razem jako niezależną hedonistkę, przedmiot męskiego pożądania. Erotyczny wizerunek kobiety wyeksponowany został w takich europejskie filmach, jak słynny Błękitny aniot (Der blaue Engel, 1930) Josefa von Sternberga (1894-1969), gdzie główną rolę zagrała Marlena Dietrich (1901-1992) o agresywnym seksapilu czy dzieła Wilhelma Pabsta (1885-1967) ze zmysłową i demoniczną Louise Brooks (19061985). Naomi z Miłości szaleńca sama ma w sobie coś dwuwymiarowego. $\mathrm{Z}$ jednej strony jest symulakrum mitycznej istoty, $\mathrm{z}$ drugiej jest tylko naiwną dziewczynką, której udaje się skutecznie usidlić męskie grono otaczających ją mężczyzn. Głównym miejscem w utworze jest Tokio i jego okolice, miejsce idealne dla modan gāru, uwielbiającej wałęsać się po sklepach i poszukiwać rozrywki. Paradoksalnie ta zatłoczona i zazwyczaj bezduszna przestrzeń ma

\footnotetext{
${ }^{30}$ Melanowicz, M. 1994. Tanizaki. Japoński most snów. Warszawa: Wilga. 25-26.

${ }^{31}$ Przechadzanie się, włóczenie się po tokijskiej dzielnicy Ginza, zazwyczaj po sklepach i lokalach.
} 
cechy romantyczne, można w niej dostrzec oznaki wpływów zachodnich, jest wypełniona tańcem i muzyką, stanowi mieszankę różnych zapachów. Narrator przedstawia ją dodatkowo w hiperboliczny sposób. Przykładowo miejscowość Kamakura $^{32}$ jawi mu się jako Wenecja. Nie bez powodu przywołuje słowa z powieści innego wybitnego japońskiego pisarza Natsume Sōsekiego (1867-

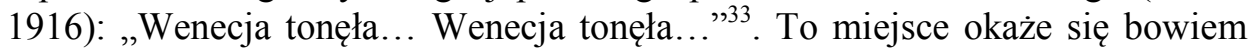
w rzeczywistości pełne zepsucia moralnego człowieka. To w tej „pseudo-idylli” Naomi codziennie oszukuje Jōjiego, przesypiając się podczas jego nieuwagi z innymi mężczyznami.

Świat w Miłości szaleńca, podobnie jak w innych utworach Tanizakiego, ma charakter tragikomiczny, niekiedy groteskowy, a nawet komiksowy. Ciężko stwierdzić, po której stronie w tym starciu tradycji z okcydentalizmem stoi autor. W pewnym okresie życia Tanizaki był gorliwym zwolennikiem tego, co zachodnie i propagatorem idei naśladowania wzorców zagranicznych, a zarazem spoglądał na świat powieściowy ironicznym, a czasem wręcz krytycznym okiem, wyśmiewając postawy wykreowanych przez siebie bohaterów. Obraz idealnej kobiety wciąż widział jednak w przedstawianych na plakatach amerykańskich gwiazdach filmowych. Mimo że wiedział, iż nie ma idealnego wyboru między tradycją a Zachodem, tęsknota za tym co nowoczesne okazała się silniejsza. Naomi zawładnęła marzeniami i pragnieniami swojego Pigmaliona. Budząc się do życia, stała się wierną kopią jego wybujałych, odrobinę chorych, sadomasochistycznych fantazji. Stopniowo zdaje sobie sprawę z własnej mocy oddziaływania na innych i nie martwi się o swój los. Wie, że ustanowi nowy porządek, w którym będzie mogła robić co chce, dostawać co chce, a mężczyzna zawsze będzie jej uległy. Ta nowonarodzona, niemal tryumfalna bogini jest jakby ucieleśnieniem Zachodu, który ostatecznie wpisał się w japońską tradycję, niejednokrotnie ją zagłuszając. Przyrównując jednak zdominowanego Jōjiego, który pogodził się ostatecznie ze swym losem, do oględnego i wyrachowanego Higginsa, współczucie odczuwamy tylko w stosunku do tego pierwszego i mimo że jest on jedynie zaślepionym głupcem, nawet trochę mu współczujemy.

Na duży ekran powieść Tanizakiego postanowił przenieść reżyser Masumura Yasuzō (1924-1986), który obok Ichikawy Kona (1915-2008) zasłynął jako najsłynniejszy adaptator utworów japońskiego pisarza. Obok Miłości szaleńca (Chijin no ai, 1967) w swoim dorobku ma również $W$ wirach namiętności (Manji, 1964), czy luźno oparty na krótkim opowiadaniu Tatuaż (Irezumi 1964). W jego pozostałych filmach, między innymi takich, jak Żona Seisaku (Seisaku no tsuma, 1965), Czerwony Aniot (Akai tenshi, 1966) czy Ślepa Bestia (Mōjū, 1969) panuje mrok i często satyryczny, niepokojący klimat z domieszką erotyki.

\footnotetext{
${ }^{32}$ Miasto w Japonii w prefekturze Kanagawa, położone ok. $50 \mathrm{~km}$ na południe od Tokio.

${ }^{33}$ Tanizaki J. 1925. op.cit. 42.
} 
Niemalże każdy z tych filmów cechuje wysublimowana estetyka, a kamera skupia się na detalu. Doskonały warsztat reżyserski nie powinien dziwić, gdyż Masumura uczył się pod kierunkiem mistrzów włoskiej kinematografii, takich jak Luchino Visconti (1906-1976), Federico Fellini (1920-1993) czy też Michelangelo Antonioni (1912-2007). Podobnie jak Tanizaki, Masumura w swych dziełach podejmował z reguły problematykę erotyczną i wskazywał na destrukcyjny charakter miłości. Człowieka przyrównywał do zwierzęcia dążącego do zaspokojenia swych popędów seksualnych. Filmy Masumury zaklasyfikować można do filmowego nurtu pinku eiga (dosł. kino różowe), który całkowicie zdominuje japoński przemysł filmowy w latach siedemdziesiątych. Pinku eiga to określenie japońskiego kina erotycznego, choć wyraźnie trzeba zaznaczyć, że nurt ten odznacza się własnymi, jedynymi w swoim rodzaju cechami i absolutnie nie jest odpowiednikiem nurtu erotycznego w jakiejkolwiek innej kinematografii. Wpisuje się zatem w typowe tendencje naturalistyczne. Niektóre należące do pinku eiga filmy, zazwyczaj trwające trochę ponad godzinę, zrealizowane były w ciągu jednego tygodnia na taśmach filmowych $16 \mathrm{~mm}$ lub $35 \mathrm{~mm}$ i miały ograniczony budżet. Na uwagę zasługuje fakt, że oprócz wymaganej odpowiedniej ilości scen erotycznych filmy te stawały się często wyrazem poglądów politycznych. Na przykład obrazy Wakamatsu Kōjiego (ur. 1936) stanowiły próbę przeniesienia pewnych idei czy postaw życiowych na ekran. Ich stylistyka często zahaczała o groteskową feerię, graniczącą nawet ze skrajną makabreską, daleką od tego co możemy nazwać wysmakowaną erotyką. ${ }^{34}$

Filmowa Miłość szaleńca utrzymana jest w tonacji groteskowej z zaledwie delikatną, adekwatną w stosunku do powieści, dawką erotyzmu opartą głównie na miłosnych igraszkach dwójki głównych bohaterów. Bardzo trafnym pomysłem okazało się obsadzenie w roli Naomi aktorki chińskiego pochodzenia Ōkusu Michiyo (znanej lepiej pod pseudonimem Michiyo Yasuda). Wykreowana na wyuzdaną, rozbrykaną, nieokiełznaną panienkę zwodzi głównego bohatera i mimo braku finansowej niezależności doskonale wie, że ten całkowicie się od niej uzależni. Masumura streścił pierwsze rozdziały powieści, dokonując pokazu zdjęć Naomi wklejonych w kartki pamiętnika i prezentacji okresu, kiedy poznała się dwójka bohaterów. Podobnie jak w przypadku kubrickowskiej ekranizacji Lolity (1962) wiek protagonistki podwyższono, w tym wypadku do osiemnastu lat. Portrety głównych bohaterów przedstawiono w sposób karykaturalny, nadając im delikatny rys komediowy. Ta mimo wszystko nieboska komedia ma służyć ośmieszeniu pewnych typów ludzkich. Dla przykładu scena, w której główny bohater próbuje zaatakować kochanka Naomi widelcem, a ten drugi, przerażony, kaja się i uprzejmie przeprasza, bardziej przywołuje na myśl pastisz

\footnotetext{
${ }^{34}$ Sharp, J. 2008. Behind the pink curtain. The complete history of Japanese sex cinema. Godalming: FAB Press. 95-100.
} 
pojedynku dwójki zdradzanych przez kobietę mężczyzn niż realną sytuację zagrożenia. Śmiech jest jednak gorzki, gdyż wynika z ludzkiej tragedii. Sama idea ubóstwienia kobiety została zachowana $\mathrm{w}$ filmie podobnie jak inne idee zawarte w powieści, w tym również obraz demonicznej japońskiej kobiety współczesnej. Po otworzeniu się Japonii na świat (poł. XIX w.) literatura i kino japońskie stały się sztuką eklektyczną, w której przeplatają się rodzima tradycja z zachodnimi koncepcjami filozoficznymi i artystycznymi. Twórcy filmowi zaczęli zastępować manierę teatralną nowymi środkami wyrazu. W tym celu chętnie wzorowali się na rewolucyjnym wówczas kinie amerykańskim, zwłaszcza na twórczości Davida Warka Griffitha (Narodziny narodu, 1915; Nietolerancja, 1916), od którego uczyli się bardziej dynamicznego montażu. Istotny wpływ na nadanie takiego kierunku rozwoju kina japońskiego wywarł Tanizaki Jun'ichirō - autor wielu scenariuszy napisanych dla reżysera Kurihary Thomasa (znanego też pod imieniem Kisaburō; 1885-1926). Dzięki artystycznej współpracy tego duetu ${ }^{35}$ narodził się ruch „czystego kina” (jap. jun'eiga geki undō), którego główną oznaką było uwalnianie się z okowów teatralności, a zatem stosowanie montażu równoległego, stopniowe wprowadzanie serii ujęć i przeciwujęć, cięć, a także retrospekcji. Dynamiczność kamery i nowa technika montażu miały skłonić widza do koncentracji na obrazie, a nie na komentarzach dodawanych podczas projekcji przez benshi, czyli specjalnie zatrudnianych komentatorów, którzy podczas projekcji filmu nie tylko tłumaczyli napisy, ale także interpretowali i objaśniali kolejne sytuacje, wzbogacając w ten sposób treść mówionym słowem. W 1917 roku w eseju Katsudō shashin no genzai to shōrai (Teraźniejszość i przyszłość filmu) pisarz przedstawił X Muzę jako najdoskonalszą ze sztuk, stojącą ponad teatrem i najbardziej przyszłościową. Szczególnie docenił kino amerykańskie i narracyjne, a japońskich reżyserów filmowych krytykował za zbyt teatralny styl. Podkreślał też istotną rolę benshi. Akcentował ponadto rolę osób specjalizujących się jedynie w czytaniu dialogów (kowairo). ${ }^{36}$

Tanizaki, mimo że nie był ani praktykiem, ani teoretykiem filmu, wpisał się w historię kina jako jego reformator. O swej fascynacji X Muzą pisarz opowiadał ustami swoich literackich bohaterów, których styl i wymowa różnią się znacznie od powieści innych wybitnych pisarzy japońskich tamtego okresu, takich jak Kawabata Yasunari (1899-1972) czy Nagai Kafū (1879-1959). Tanizaki uczynił bowiem z wykreowanej przez siebie kobiety boski absolut, a z mężczyzny - jej niewolnika ${ }^{37}$. Dał tym samym wyraz przekonaniu o męskiej słabości.

\footnotetext{
${ }^{35}$ Do ich najważniejszych wspólnych dzieł należą: Klub amatorów (Amachua kurabu, 1920), Pożądliwość żmii (Jasei no in, 1921), Wróbel bez języczka (Shitakiri suzume, 1923).

${ }^{36}$ Loska, K. 2009. Poetyka filmu japońskiego. Kraków: RABID. 86.

${ }^{37}$ Melanowicz, M. 1994. op. cit. 41.
} 
Abstrahując jednak od kolorytu japońskiej kultury, trawestacja mitu o Pigmalionie świadczy o tym, że niezależnie od kontekstu kulturowego człowiek jest tylko człowiekiem i choć niezmiennie poszukuje ideału, nie potrafi oprzeć się zgubnym pragnieniom czy pokusom.

Można zaryzykować twierdzenie, że Tanizaki jest jednym z ważniejszych pisarzy na świecie, który stworzył utwory literackie o tematyce Pigmaliona, czego doskonałym przykładem jest Miłość szaleńca. W dodatku w rzeczywistości żył tak, jakby był osaczony przez wykreowane w kolejnych powieściach żeńskie ideały i do końca swych dni patrzył na kobiety - zwłaszcza na swoje życiowe partnerki - przez pryzmat tych właśnie ideałów. W Miłości szaleńca japoński pisarz zdaje się zwiastować pojawienie się późniejszych utworów Vladimira Nabokova (1899-1977): Śmiechu w ciemności (1938) czy nawet słynnej Lolity (1955). To Tanizaki wcześniej niż Nabokov opisze skandaliczny związek młodziutkiej rozpuszczonej, frywolnej dziewczyny i starszego od niej dojrzałego mężczyzny, przywoła motyw kina i zaakcentuje jego rolę w życiu bohaterów, a przede wszystkim nie da za wygraną cenzurze, która uzna jego utwory za skandaliczne i gorszące. Tanizaki, trochę na przekór krytyce i czytelnikowi, zdaje się z nutką ironii mówić, że miłość ma różne oblicza, i nie ma znaczenia, jaka jest, ponieważ zawsze zawiera ona w sobie pierwiastek sacrum.

Podczas zajęć z literatury poświęconych Miłości szaleńca Tanizakiego, japońskie studentki zwracają uwagę na element męskiego szowinizmu w utwo$\mathrm{rze}^{38}$. Pigmaliona $\mathrm{z}$ powieści Tanizakiego cechuje bowiem egoistyczna postawa polegająca na tym, że swoją idealną kobietę, niezależnie od formy, ożywionej czy nieożywionej, chcą mieć na wyłączność dla siebie i myślą jedynie o swoim szczęściu lub korzyści. Duże kontrowersje wzbudzają też sadomasochistyczne bądź masochistyczne preferencje bohaterów utworu. Tanizaki, pisząc swoje powieści, niewątpliwie inspirował się twórczością Leopoloda von Sacher-Masocha (1836-1895), w tym jego najsłynniejszym dziełem Wenus w futrze (Venus im Pelz, 1870).

Niektórzy japońscy studenci twierdzą, że przebywanie z ideałem wcale nie musi oznaczać szczęścia. Wręcz przeciwnie, spotkanie ideału może być równie przerażające, jak spotkanie własnego sobowtóra - zasugerowała jedna ze studentek. To też potwierdza tezę Shawa, że zbyt bogopodobny stosunek Pigmaliona do Galatei wcale nie musi być przyjemny. Podobnie Alicja Helman kończy swój artykuł: „Mit o Pigmalionie i Galatei ma szczęśliwe zakończenie. Pobrali się, mieli dzieci, darzyli się miłością. Ale to tylko piękna bajka. W rzeczywistości

\footnotetext{
${ }^{38}$ Na podstawie obserwacji Nikodema Karolaka - uczestnika tych zajęć.
} 
Pigmalion obawiałby się żywej Galatei i jak Hideo z Dmuchanej lali wolałby, aby na powrót stała się posągiem". ${ }^{39}$

„Marzenia i rzeczywistość rzadko kiedy chodzą w parze - stwierdza Tanizaki Jun'ichirō w eseju Renai to shikijō (Miłość i pożadanie, 1931). Musi minąć wiele pokoleń kształtowania się charakterów japońskich kobiet, by tak jak kobiety Zachodu wydostały się z okowów tradycji. Przyznać muszę, że jako młodzieniec byłem jednym $\mathrm{z}$ tych, którzy mieli to niedorzeczne marzenie i czułem się niesamowicie smutny z tego powodu, że nie spełni się ono niestety w moim pokoleniu". ${ }^{40}$

Obserwując współczesne, naśladujące zachodni styl życia społeczeństwo japońskie, można stwierdzić, że stało się one tworem synkretycznym, łączącym w sobie tradycję i zachodnie wzorce kulturowe. Japończycy chętnie zapożyczają słowa z języka angielskiego, kupują choinkę na Boże Narodzenie czy świętują Halloween. Zaglądając do współczesnej dzielnicy Ginza czy Roppongi w Tokio, zauważyć można wiele Japonek ubranych w stylu amerykańskim, przechadzających się dla rozrywki od sklepu do sklepu. Jest to właśnie taki świat, o którym tak bardzo marzył Tanizaki Jun'ichirō. Być może pośród tych kobiet błąka się jakaś podobna do powieściowej Naomi dziewczyna niecierpliwie wyczekująca swojego Pigmaliona.

\section{Bibliografia}

Graves, R. 1968. Mity greckie. Warszawa: Państwowy Instytut Wydawniczy.

Helman, A. 2010. „Portrety filmowe: Pigmalion”. Kino 10. 66-70.

Huang Yiju. 2007. "A man awakened from dreams: rereading the modern girl image in A fool's love by Tanizaki Jun'ichirō”. Graduate Journal of Asia-Pacific Studies 5(2). 77-87.

Janicki, S. 1982. Film japoński. Warszawa: Wydawnictwa Artystyczne i Filmowe.

Keene, D. 1998. Dawn to the West: Japanese literature of the modern era. Nowy Jork: Columbia University Press.

Keene, D. 2003. Five modern Japanese novelists. Nowy Jork: Columbia University Press.

Loska, K. 2009. Poetyka filmu japońskiego. Kraków: RABID.

Melanowicz, M. 1994. Tanizaki. Japoński most snów. Warszawa: Wilga.

Parandowski, J. 1992. Mitologia. Londyn: Puls.

Reynolds, J. 1999. Pygmalion's wordplay: the postmodern Shaw. Gainesville, FL: University of Florida Press.

Sharp, J. 2008. Behind the pink curtain. The complete history of Japanese sex cinema. Godalming: FAB Press.

\footnotetext{
${ }^{39}$ Helman, A. 2010. op.cit. 67.

${ }^{40}$ Tanizaki J. 1985. Tanizaki Jun'ichirō Zuihitsushū. Tokio: Iwanami Shoten.
} 
Shaw, B.G. 1977. Pygmalion. Tłum. Florian Sobieniowski. Warszawa: Państwowy Instytut Wydawniczy.

Tanizaki Jun'ichirō. 1925. Chijin no ai. Tokio: Shinchōsha.

Tanizaki Jun'ichirō. 1969. Shisei. Tokio: Shinchōsha.

Tanizaki Jun'ichirō. 1972. Niektórzy wola pokrzywy. Tłum. Mikołaj Melanowicz. Warszawa: Państwowy Instytut Wydawniczy.

Tanizaki Jun'ichirō. 1985. Tanizaki Jun 'ichirō Zuihitsushū. Tokio: Iwanami Shoten. 
